\title{
CORPORATE SOCIAL RESPONSIBILITY (CSR): PROFIT SEEKING OR SOCIAL ACTIVITY?
}

\author{
Nia Hariana ${ }^{1}$ \\ Arthik Davianti $\left.^{2}\right)^{*}$ \\ 1), 2) Economic and Business Faculty, Satya Wacana Christian University \\ Corresponding author : arthik.davianti@uksw.edu
}

Accepted 20 May 2020 / Approved 11 August 2020

\begin{abstract}
A company is required to do the Corporate Social Responsibility (CSR) as a form of responsibility to the stakeholders. In general, CSR activities give several impacts on companies and also the surrounding environment or residents. Companies tend to spend a high CSR expenditure with a possibility to influence their profit but some argue that CSR expenditure is related to companies' social objectives. The research was conducted with the aim to analyze the effect of CSR on future financial performance and corporate social activity. The data of the research uses secondary data through the annual report and financial report of consumer goods manufacturing industries that registered in the Indonesia Stock Exchange. The result of the research showed that CSR expenditure has no significant effect on future financial performance. However, the company will still report their CSR expenditure as a signal to the users of financial statements. Further, the result of this study shows that CSR expenditure has a significant effect on social activities. This research can be used by shareholders, investors, and other companies in choosing a company with a good image seen from their CSR to work with. Afterward, further research is expected to use other moderating variables such as Return on Equity (ROE) or Earning per Share (EPS) in measuring the relationship of CSR and financial performance.
\end{abstract}

Keywords: Corporate social responsibility, future financial performance, corporate social activity.

ABSTRAK: Sebuah perusahaan wajib melakukan Tanggung Jawab Sosial Perusahaan sebagai bentuk tanggung jawab kepada para pemangku kepentingan. Secara umum, kegiatan Tanggung Jawab Sosial Perusahaan memberikan beberapa dampak bagi perusahaan dan juga lingkungan atau atau masyarakat sekitar. Perusahaan cenderung mengeluarkan pengeluaran atas Tanggung Jawab Sosial Perusahaan dengan cukup tinggi dengan harapan dapat mempengaruhi keuntungan perusahaan. Akan tetapi, beberapa berpendapat bahwa pengeluaran dari Tanggung Jawab Sosial Perusahaan berhubungan dengan tujuan sosial perusahaan. Penelitian ini dilakukan dengan tujuan untuk menganalisis pengaruh Tanggung Jawab Sosial Perusahaan terhadap kinerja keuangan masa depan dan aktivitas sosial perusahaan. Data penelitian menggunakan data sekunder melalui laporan tahunan dan laporan keuangan industri manufaktur barang konsumsi yang terdaftar di Bursa Efek Indonesia (BEI). Hasil penelitian menunjukkan bahwa pengeluaran atas Tanggung Jawab Sosial Perusahaan tidak berpengaruh signifikan terhadap kinerja keuangan masa depan perusahaan. Meski demikian, perusahaan tetap akan melaporkan pengeluaran atas Tanggung Jawab Sosial Perusahaan sebagai sinyal bagi pengguna laporan keuangan. Lebih lanjut, hasil penelitian ini menunjukkan bahwa pengeluaran atas Tanggung Jawab Sosial Perusahaan berpengaruh signifikan terhadap kegiatan sosial perusahaan. Penelitian ini dapat digunakan oleh pemegang saham, investor, dan perusahaan lain dalam memilih perusahaan dengan citra yang baik dilihat dari Tanggung Jawab Sosial Perusahaan untuk kepentingan menjalin kerjasama. Selanjutnya penelitian berikutnya diharapkan dapat menggunakan variabel moderasi lain seperti laba atas ekuitas atau penghasilan per saham dalam mengukur hubungan Tanggung Jawab Sosial Perusahaan dan kinerja keuangan perusahaan.

Kata kunci: Tanggung jawab sosial perusahaan, kinerja keuangan masa depan, aktivitas sosial perusahaan. 
Introduction

Background

Corporate Social Responsibility

(CSR) is a concept that shows the company's responsibilities to the shareholders, government, consumers, the competitors, and the environmentalist (Bhardwaj, Chatterjee, Demir, \& Turut, 2018). In practice, a company that carries out the CSR activity might be driven by the purpose of increasing financial performance or just to deliver some benefit is to society. A company commonly provides charity activities, such as scholarships, free health care, parental and child care, or nature preservation, to benefit society. Usually, a company would do relatively plenty of innovations of CSR activities with the expectation for strong financial performance in the future (Lys, Naughton, \& Wang, 2015).

In Indonesia, many companies have carried out CSR activities. The activities take many forms of CSR. CSR activities in Indonesia usually take the form of activities that could be expected to increase the prosperity of people in Indonesia, as well as maintain and build the environment. Further, many CSR actions in Indonesia are also in the form of scholarships. PT. Bhimasena Power Indonesia, which was awarded the Asia Responsible Entrepreneurship Award (AREA), is one of the examples of companies applying CSR in Indonesia. PT Bhimasena Power Indonesia has five main CSR activities. They are economic development, health quality improvement support, education quality improvement support, infrastructure for public facilities support, and social and cultural activities support.

Another example is from PT. Pertamina, which focuses on five main pillars to perform their CSR activities: education, environment, social empowerment, and social/religious. PT. Pertamina provides Health, Safety, Security, and Environment (HSSE) training for Junior High School Students since 2015 as an embodiment of the education pillar. Besides, as an environmentally wise company, PT. Pertamina also planted trees around the mosque in Jakarta as an implementation of the environment pillar (https://www.pertamina-ptc.com/csr/).

Signaling theory is a theory that focuses on mitigating asymmetric information that means differences in receiving information between the internal parties of the company with the external parties of the company (Spence, 2002). Asymmetric information happens due to the internal parties believe that they know more about the company compared to the external ones (Papaioannou \& Karagozoglu, 2017). Utomo et al., (2017) explained in their study that a company publishes financial statements to provide market information in the hope that the market can respond to the information provided as a positive or negative signal. Thus, the condition of the company shown through signals to the public such as published financial statements could affect the stock market such as the company's stock price. In addition, corporate sustainability report also can be used as a signal to the public (Utomo et al., 2017).

$\mathrm{Su}$ et al., (2016) explained in their study that CSR expenditure could be a signal that provides additional management information to the shareholders. There are two conditions of quality signal when a company do the CSR (Spence, 1973). First, when doing CSR in a low-capability company, the cost and effort needed are higher than in the high-capability company. Second, the premium for the company to take part in CSR is only enough for the high-capability firms. A Company will spend many costs on CSR expenditure. Still, it would work off when the company receives "stakeholder influence capacity" which means the CSR expenditure that can improve stakeholder relationships by identifying and reacting on profit from opportunities (Barnett, 2007).

Freeman (2010) specified in his study that a stakeholder is an organization or a group that can give affect or be affected by the organization's objectives. Moreover, Mitchell (1997) described that the stakeholder theory explains that the company should give their attention to the stakeholder's potential to affect the company's value. Stakeholder Theory can 
be described as two approaches: a descriptive and normative view (Lozano, 2005). The descriptive stakeholder perspective recognizes and classifies the different elements of a company or organization and does not define the value statements based on the legitimacy of the company's or organization's power (Lozano, 2005). However, the normative shareholder approach will explain the reason why the company needs to consider the stakeholder claim (Donaldson \& Preston, 1995).

Stakeholder theory explains that the essence of a business is in the relationship and adding value for its stakeholders. However, Ridho (2018) found that the composition of stakeholder theory applied in each company is different; it depends on the industry and the stakeholder's business form. Stakeholders that consist of suppliers, customers, owners, employees, and investors are all critical for the company. All stakeholders need a way to be in the same direction.

CSR or Corporate Social Responsibility is the relation between the corporation with the governments or the relationship between the corporation with the individual citizens (Crowther \& Aras, 2008). Moreover, the European Commission (2006) described CSR as the concept of a company's work that might help the society and also build a better environment; this action needs interactions that the stakeholder wants. Crane, A., Matten, D., Spence (2008) pointed in their book that CSR could be specified into six main characteristics. First, CSR is defined as voluntary and CSR activities that exceed the required disclosure regulation. Second, CSR activities manage externalities, such as a company builds a healthier environment by planting trees. Third, CSR focuses on the responsibility to the suppliers, employers, consumers, shareholders, and local communities. This CSR characteristic is called a multiple stakeholder orientation. The fourth is an alignment between social and economic elements that explained the way CSR should not contradict with the profit-seeking objectives. The fifth characteristic of CSR is its practices and values. Lastly, CSR works beyond philanthropy, which means the CSR should be combined in the primary business in the company and not only philanthropy or community projects. Several regulations manage CSR activities for the company in Indonesia. The followings are the regulations regarding CSR practice in Indonesia:

1. Article 1 Number 3 Law No. 40 of 2007, stated that "Social and Environmental Responsibility shall be a commitment of Corporation to take parts in sustainable economic development to develop life quality and beneficial environment either for the Corporation itself or site community or the public."

2. Article 15, point b Law. 25 of 2007, stated that "Each investor is obliged to meet corporate social obligations."

Previous research conducted by Sayekti (2015) concluded that a company's financial performance is positively affected by the level of strategic CSR level. Further, the study also explained that CSR activities should also give benefits to the company, not only for its stakeholders. Similarly, Ridho (2018) found that the implementation of CSR activities has a significant and positive effect on the company's financial performance. Moreover, Cho \& Park (2015) specified in their study done in Korea, that the managers tend to be more proactive to catch up the CSR if the CSR has a positive relationship with the Corporate Financial Performance. Also, Bhardwaj et al. (2018) explained in their study that the gain from CSR could be very high if the company invests in CSR-CA. However, Lys (2015) claimed that CSR expenditure that the company makes in the current period is in purpose to anticipate the strong future financial performance.

CSR activities have several impacts on companies and also the surrounding environment or residents. An example of the effects of CSR activity on the environment is there are more wellmaintained places in Indonesia. Widiastuty \& Soewarno (2019) stated that CSR expenditure is related to companies' social 
objectives. However, with CSR activities, companies could tend to spend a high CSR expenditure with a possibility to influence their profit (Iskandar, 2016).

\section{Identification of Problem}

Based on the existing phenomena and previous research, problem that arise can be identified. The problem is, on average, companies in Indonesia have carried out their CSR activities. Some companies carry out their CSR activities normally but some companies tend to spend a high CSR expenditure for their CSR activities. From these circumstances, the question arises regarding the purpose of the company in carring out their CSR activities. Are CSR activities really profitable for the company, or does the company do the CSR activities for social purposes?

\section{Research Objectives and Benefits}

Based on the identification of the problem in this research, the objective of this study is to analyze companies' CSR expenditure concerning companies' future financial performance or CSR activities, which have social and environmental purposes. This study focuses on the consumer goods industry in Indonesia. Consumer goods industry is a sector that produces ready to consume products without further processing needed. The reason this research uses the consumer goods industry sector is because companies in this sector directly involve community such as providing jobs or for peoples and providing people's needs. The other reason is companies in this sector have the highest growth rate compared to companies in other sectors, therefore it can survive the global crisis and continue to implement (Nisa, 2018). This study would help to the CSR reference studies by CSR expenditure as a point of interest and investigation on CSR practices in the consumer goods industry. Few research discuss about CSR expenditure and relates them to company performance, in general the Corporate Social Responsibility (CSR) issues is on the actual purpose of the company doing their Corporate Social Responsibility (CSR) .

\section{Hypothesis Development}

A study from Cho \& Park (2015) explained the impact of CSR on the profitability in Korea. They said that CSR has a significant effect on the profitability of a company. If CSR has a positive relationship with the Corporate Financial Performance, the managers will chase the CSR activities. If the CSR has a negative CFP relation, then the manager should be careful when investing in CSR. Furthermore, Chang (2018) mentioned that the company should manage the CSR expenditure because if it is too high, it will have an adverse impact on the company profit.

One of the examples that Chang provides is when a company tends to pay higher CSR expenditures, it will have an impact on the difficulties to pay the employees' salaries. However, Lys et al. (2015) specified that the CSR expenditures spent by the company for the CSR activities are to anticipate the strong future financial performance. In Indonesia, CSR expenditures also have a significant impact on the firm's future financial performance. How CSR expenditures influence financial performance was explained by Andreas (2015) in his research focusing on mining companies in Indonesia, which shows the significant impact of CSR expenditures on the company's profitability. Based on these arguments:

$\mathrm{H}_{1:}$ Corporate Social Responsibility (CSR) expenditure influences the company's future financial performance.

Contrary to that, Campbell (2007) argued in his theory that only a company that surplus in current corporate resources will be asked to spend some amount of their corporate resources on the purpose of social investments. Similar to his theory, Hong, Kubik, \& Scheinkman (2012) found that a company with a surplus in current financial slack will do CSR initiatives. These two studies were simplified by Lys et al. (2015), suggesting that CSR initiatives are using corporate resources, which means CSR 
expenditure is one of the corporate charity forms. CSR expenditure can also show a form of philanthropy, where the company will do something in the form of charitable contributions for it is stakeholders (Benabou \& Tirole, 2010). A research conducted in Indonesia also showed that CSR expenditure spent by a company is not only to gain some profit in the future, but it is also used to give several benefits to the society, economy, and environment (Meilanny \& Raharjo, 2016). Based on the arguments:

$\mathrm{H}_{2:}$ Corporate Social Responsibility (CSR) expenditure influences the company's social activities.

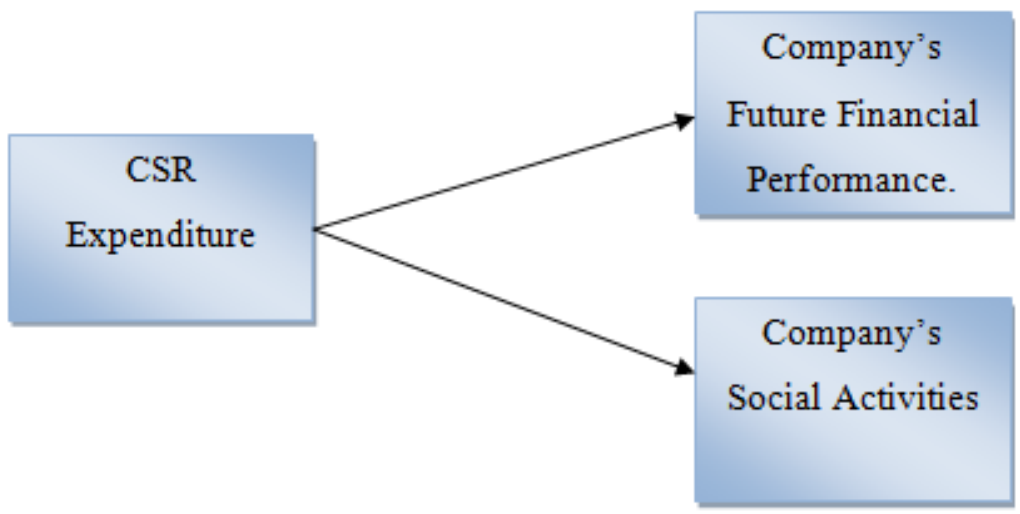

Figure 1. Model Framework

\section{Research Method}

\section{Data}

The data used in this research is secondary data. The data consists of the financial statement and annual report of the company published by Bursa Efek Indonesia on their website, www.idx.co.id from 2015 until 2018.

\section{Population and Sampling}

The population and sample in this research are all manufacturing companies in the consumer goods industry registered in Bursa Efek Indonesia. Sample selection in this research is using purposive sampling with several criteria. These criteria are: first, manufacturing companies in the consumer goods industry that have been registered on Bursa Efek Indonesia at least from 2015 until 2018. Second, the company published audited financial statements and annual reports. Third, the company that does not stated their corporate social activity and CSR expenditure on the corporate sustainability report.
Table 1. Sample Selection Procedure

\begin{tabular}{|l|c|}
\hline \multicolumn{1}{|c|}{ Information } & Amount \\
\hline $\begin{array}{l}\text { Manufacturing companies in } \\
\text { the consumer goods industry } \\
\text { registered in BEI from 2015- } \\
2018\end{array}$ & 37 \\
\hline $\begin{array}{l}\text { Manufacturing companies in } \\
\text { the consumer goods industry } \\
\text { that the financial report and } \\
\text { annual report are not presented } \\
\text { in rupiah }\end{array}$ & $(4)$ \\
\hline $\begin{array}{l}\text { Manufacturing companies in } \\
\text { the consumer goods industry } \\
\text { that the Corporate Social } \\
\text { Activity and CSR Expenditure } \\
\text { are not stated }\end{array}$ & $(7)$ \\
\hline $\begin{array}{l}\text { Companies that meet the } \\
\text { requirements }\end{array}$ & 26 \\
\hline Unit of observation & 104 \\
\hline
\end{tabular}

From the 37 manufacturing companies in the consumer goods industry registered in BEI, 26 companies met the requirements. For four periods of observation, there are 104 units of 
observation used as the sample. All of the samples will be processed to see whether CSR expenditures have an impact on a company's future financial performance or to the company's social activities or not.

\section{Model and Variables}

This research uses multiple regression as the data analysis method because this research has two dependent variables, which are profitability and corporate social activities and one independent variable, which is Corporate Social Responsibility. These two dependent variables are affected by several control variables. As the company's future financial performance, it is affected by the firm's size and leverage. The company's social activities are affected by firm size, profit, and leverage (Lys et al., 2015).

The model of the first hypothesis is as follows:

$\mathrm{FFP}_{(\mathrm{t}+1)}=\operatorname{CSREXP}_{(\mathrm{t})}+\mathrm{FRMSZE}_{(\mathrm{t})}+$

$\mathrm{LVRGE}_{(\mathrm{t})}+\mathrm{e}$

Where:

$\mathrm{FFP}_{(t+1)} \quad=$ Future Financial Performance in $\mathrm{t}+1$ period

$\operatorname{CSREXP}_{(\mathrm{t})}=\mathrm{CSR}_{\mathrm{f}}$ Expenditure in $\mathrm{t}$ period

FRMSZE $_{(\mathrm{t})}=$ Firm Size

$\operatorname{LVRGE}_{(\mathrm{t})}=$ Leverage

The model of the second hypothesis is as follows:

$\mathrm{CSA}_{(\mathrm{t})}=\mathrm{CSREXP}_{(\mathrm{t})}+\mathrm{FRMSZE}_{(\mathrm{t})}+$

PROFT $_{(\mathrm{t})}+\mathrm{LVRGE}_{(\mathrm{t})}+\mathrm{e} \ldots \ldots \ldots . .(2)$

Where:

$\mathrm{CSA}_{(\mathrm{t}-1)}=$ Corporate Social Activities in t-1 period

$\operatorname{CSREXP}_{(\mathrm{t})}=$ CSR Expenditure in $\mathrm{t}$ period

FRMSZE $_{(\mathrm{t})}=$ Firm Size

LVRGE $_{(\mathrm{t})}=$ Leverage

\section{CSR Expenditures}

This research measures the CSR expenditures by looking at the amount of CSR expenditures in Indonesian Rupiah (IDR). From the amount of CSR expenditures, it could be seen whether the increase of CSR expenditure increases from the corporate social activities, or maybe the rise of CSR expenditure has an effect on the increase of the company's future financial performance.

\section{Financial Performance}

The measurement of the firm's financial performance in this research utilized the future changes in Return on Assets (ROA). This research used Return on Assets (ROA) as the measurement because this ratio measures the company's profitability by looking at how well management uses its assets to increases its operations (Pratama \& Achmad, 2015). The formula of Return on Asset (ROA) used in this research based on Kurniasari (2017) is

$$
\mathrm{ROA}=\frac{\text { Net Income }}{\text { Total Assets }} \times 100 \%
$$

The Return on Assets is calculated by looking at the company's statement of financial positions for total assets and income statement for net income.

\section{Corporate Social Activities}

Corporate Social Activities can be measured by the total amount of CSR activities that a company does in a certain period of time. CSR expenditures has a role to finance CSR activities (Lys et al., 2015).

\section{Firm Size}

Firm size is the size of a company in a certain period of time that can result in the lowest cost of production per unit of output. Firm size can be measured by amount of total assets because assets can measure the size of the company appropriately. The bigger the company, the easier access for getting funds, and the higher the agency cost will be (Falirat et al., 2018).

\section{Profit}

Profit is the total amount of cash the company gets from selling goods and services after the company reduces it with all fixed costs and the costs related to the provisions of goods and services. In other words, profit can be measured by 
subtracting the total revenue with the expenditures.

\section{Leverage}

Leverage is the use of assets and sources of funds in a company that has fixed costs in an objective of increasing the profit of the potential shareholders. Leverage in this research is measured by Debt to Assets Ratio (DAR) because DAR can measure how well the company in closing its debt through assets. Irawati (2012) stated on their study that "Leverage is a policy that company makes to invest the funds or to get a source of funds that followed by cost or fixed costs that are borne by the company."

\section{Assumptions}

This research uses classic assumption tests to analyze whether there are problems of classical assumptions in the regression model. There should be several tests for the data, as follows:

\section{Normality Test}

Normality Test has the aim to test whether the regression model used in this research has a normal distribution. The regression model should have a normal distribution or close to normal. Test of Normality Kolmogorov-Smirnov is used to test the normality of the data. Normality is tested by the probability (Asymptotic Significance). If the probability $>0,05$, the distribution of THE regression model is normal. If the probability $<0,05$, the distribution of the regression model is not normal (Ghozali, 2016).

\section{Multicollinearity Test}

Ghozali (2016) explained that a multicollinearity test is used to see the area of correlation between independent variables. In a functional regression, there should be no correlation between the independent variables. If there is a correlation between independent variables, it IS called a multicollinear problem. Multicollinearity can be tested by using the Variance Inflation Factor (VIF) and Tolerance. If the VIF value is less than 10, there are no symptoms of multicollinearity in the data. Tolerance number must close to one so that the regression model is free from the symptoms of multicollinearity.

\section{Autocorelation Test}

Autocorelation test is used to test whether there is a correlation in the regression model between the error in the current period and the error in the previous period. Autocorrelation can be tested using the Durbin-Watson (DW) test. Based on Ghozali (2016), the decision in the DW test can be taken as followed:

1. There is no correlation if DU $<\mathrm{DW}<$ 4-DU so that $\mathrm{H}_{0}$ is accepted.

2. There is a correlation if $\mathrm{DW}<\mathrm{DL}$ or DW $>4$-DL so that $\mathrm{H}_{0}$ is rejected.

3. There is no decision if $\mathrm{DL}<\mathrm{DW}<\mathrm{DU}$ or 4 -DU $<$ DW $<4-\mathrm{DL}$.

\section{$\underline{\text { Heteroscedasticity Test }}$}

Heteroscedasticity test used to test whether there is inequality of variance in the regression model, from the residual in one observation to another. Heteroscedasticity can be tested using several tests; one of them is the Spearman's rho correlation coefficient test. This research will use a plot graph by observing the dots pattern. Heteroscedasticity will not occur if there is no clear dots pattern, and the dots spread above and below number 0 in Y-axis (Ghozali, 2016).

\section{Hypothesis Testing}

This research uses multiple linear regression analysis for the hypothesis testing. This analysis has a purpose to see the impact of the independent varaibles against the dependent ones. This research will use t-test and F-test for the linear analysis. The regression model of this research is:

$\mathrm{FFP}_{(t+1)}=\operatorname{CSREXP}_{(\mathrm{t})}+\operatorname{FRMSZE}_{(\mathrm{t})}+$ $\operatorname{LVRGE}_{(t)}+\mathrm{e}(1)$

and

$\mathrm{CSA}_{(\mathrm{t})}=\operatorname{CSREXP}_{(\mathrm{t})}+\mathrm{FRMSZE}_{(\mathrm{t})}+$ $\operatorname{PROFT}_{(\mathrm{t})}+\mathrm{LVRGE}_{(\mathrm{t})}+\mathrm{e}(2)$

Where:

$\operatorname{FFP}_{(t+1)}=$ Future Financial Performance in $\mathrm{t}-1$ period 
$\mathrm{CSA}_{(\mathrm{t})}=$ Corporate Social Activities in $\mathrm{t}-1$ period

$\operatorname{CSREXP}_{(\mathrm{t})}=\mathrm{CSR}$ Expenditure in $\mathrm{t}$ period

FRMSZE $_{(\mathrm{t})}=$ Firm Size

$\operatorname{LVRGE}_{(\mathrm{t})}=$ Leverage

$\alpha \quad=$ constant

$\beta \quad=$ beta (regression coefficient)

et $\quad=$ error

\section{T-Test}

The objective of this test is to see how big the effect of the independent variable on the dependent ones. This ttesting on this research will use the level of confidence of 0,95 and the significance level of 0,05 or $\alpha=5 \%$.

\section{$\underline{\text { F-Test }}$}

The objective of this test is to see whether the dependent variables in this research are influenced by the independent variable included in the regression model. This f-testing also uses the significance level of 0,05 or $\alpha=5 \%$.

\section{Results And Analysis Classical Assumption Test}

The classical assumption tests are conducted in this research with the aim that the regression results are accurate estimations. The normality test of both regression models in this research uses the Kolmogorov-Smirnov Test by observing the significance value. The result of normality test showed that in the first regression model the data is normally distributed because the significance value $(p)$ is $0,05(p=0,05)$ and it has reached the significance level $(\alpha=0,05)$. In the second regression model, the normality test result showed that the significance value $(p)$ obtained is 0,2. Therefore, the data of second regression model is normally distributed because it exceeds the significance level $(\alpha=0,05)$.

Furthermore, multicollinearity test in this study was conducted by observing the tolerance value and VIF of the multicollinearity test result. The results showed that the tolerance value of CSR Expenditure is 0,431, Firm Size is 0,425, and Leverage is 0,960 . There is no tolerance value of the independent variable that less than 0,10 . VIF calculation results also show that there is no VIF value of the independent variable that is more than 10 . The VIF value of CSR Expenditure is 2,323, Firm Size is 2,353, and Leverage is 1,042. Therefore, it can be concluded that there is no multicollinearity problems between the independent variables in the first regression model.

Hereinafter, the tolerance value of independent variable in the second regression model is more than 0,10 . The tolerance value of CSR Expenditure is 0,429, Firm Size is 0,116, Profit is 0,148, and Leverage is 0,915. From the VIF calculation, the VIF value of CSR expenditure is 2.330, Firm Size is 8.601, Profit is 6.764, and Leverage is 1.093 which means that there is no VIF value that exceeds 10 . Thus it can be concluded that there is no multicollinearity problems between the independent variables in the second regression model.

The autocorrelation test for both regression models in this research uses the Durbin Watson test. The value of Durbin Watson of first regression model is 1,036 while the total samples are $104(n=104)$ and the total variables are $3(\mathrm{k}=3)$. Therefore the value of Durbin Lower (dL) obtained from the Durbin Watson table is 1,6217. Because of the value of Durbin Watson is 1,036 lower than $\mathrm{dL} 1,6217$, then it can be concluded that there is a positive autocorrelation between variables in the first regression model. In the second regression model, the value of Durbin Watson is 0,913 with the total samples of $104(n=104)$ and total variables of $4(\mathrm{k}=4)$. Therefore, the value of Durbin Lower (dL) obtained from the Durbin Watson Table is 1,6016 which means that the Durbin Watson value $(0,913)$ is lower than $\mathrm{dL}$ $(1,6016)$. It can be concluded that there is an autocorrelation between variables in the second regression model.

Moreover in the heteroscedasticity test, this research uses the scatterplots test by considering the distribution of dots on the graph. The dots in the graph of the data in first regression model are spread above and below the number zero in $\mathrm{Y}$ axis. Also, 
The dots are not scattered only on the top or bottom side. Furthermore, the dots do not show a particular pattern. Therefore, it can be concluded that in the first regression model there is no heteroscedasticity problem. On the second regression model, the dots in the graph are scattered above and below the number zero in $\mathrm{Y}$ axis. Furthermore, the dots do not gather only at the top or bottom side. Also, the dots do not show a particular pattern. Therefore, it can be concluded that there is no heteroscedasticity problem in the second regression model.

\section{Hypothesis Testing}

This research will use multiple linear testing to test the hypotheses and as well as the Partial Test (t-Test) and Simultaneous Test (f-Test) as the linear analysis.

\section{$\underline{\text { T-Test }}$}

Partial test was conducted to see the influence of the independent variable on the dependent variables. The results of the tTest of both regression models are shown in following tables.

Table 2. t-Test of CSR Expenditure on Future Financial Performance

\begin{tabular}{|c|c|c|}
\hline & & \\
& $\mathrm{t}$ & Sig. \\
\hline (Constant) & -6.872 & .000 \\
CSR Expenditure & -.580 & .563 \\
Firm Size & 4.286 & .000 \\
Leverage & -2.194 & .031 \\
\hline
\end{tabular}

According to table above, the CSR Expenditure has a t value of $-0,580$ and a significance value of 0,563 . The significance $t$ value is bigger than $\alpha(0,05)$ which means there is no significant influence between CSR expenditure and future financial performance. Moreover, Firm Size has a $\mathrm{t}$ value of 4,286 with a significance value of 0,000 . The significance $t$ value is smaller than $\alpha(0,05)$ which means there is a significant influence between firm size and future financial performance. Furthermore, Leverage has a $t$ value of $-2,194$ with a significance value of 0,031 . The significance $t$ value is smaller than $\alpha(0,05)$ which means there is a significant influence between leverage and future financial performance.

Table 3. t-Test of CSR Expenditure on Corporate Social Activity

\begin{tabular}{|c|c|c|}
\hline Model & $\mathrm{t}$ & Sig. \\
& & \\
\hline (Constant) & -2.155 & .034 \\
CSR Expenditure & 3.929 & .000 \\
Frim Size & -.926 & .357 \\
Profit & .909 & .365 \\
Leverage & -.886 & .378 \\
\hline
\end{tabular}

According to table above, the CSR Expenditure has a t value of 3,929 with a significance value of 0,000 . The significance $t$ value is smaller than $\alpha(0,05)$ which means there is a significant influence between CSR expenditure and corporate social activity. Furthermore, Firm size has a $\mathrm{t}$ value of $-0,926$ with a significance value of 0,357 . The significance $t$ value is bigger than $\alpha(0,05)$ which means there is no significant influence between firm size and corporate social activity.

Hereinafter, the Profit has a $t$ value of 0,909 with a significance value of 0,365 . The significance $\mathrm{t}$ value is bigger than $\alpha$ $(0,05)$ which means there is no significant influence between profit and corporate social activity. For Leverage, it's has a $t$ value of $-0,886$ with a significance value of 0,378 . The significance $t$ value is bigger than $\alpha(0,05)$ which means there is no significant influence between profit and corporate social activity.

\section{F-Test}

Simultaneous test was conducted in this research to see whether the dependentvariables in this research are influenced by the independent variable. The 
results of f-Test of both regression models are in the tables below.

Table 4. f-Test of CSR Expenditure on Future Financial Performance

\begin{tabular}{|c|c|c|}
\hline Model & F & Sig \\
\hline Regression & 11.674 & .000 \\
\hline
\end{tabular}

From table above, the significance value is 0,000 which is smaller than $\alpha=0,05$. Furthermore, the value of F-count is 11,674 which is higher than the value of $F$ table $(2,69)$. Therefore the CSR expenditure, firm size, and leverage have a significant influence on future financial performance.

Table 5. f-Test of CSR Expenditure on Corporate Social Activity

\begin{tabular}{|c|c|c|}
\hline Model & F & Sig \\
\hline Regression & 7.840 & .000 \\
\hline
\end{tabular}

In table 10 , the significance value is 0,000 which smaller than $\alpha=0,05$. Moreover, the value of F-count is 7,840 which is higher than the value of $\mathrm{F}$ Table $(2,46)$. Therefore it means that CSR expenditure, firm size, profit, and leverage have a significant influence on the corporate social activity.

\section{Analysis}

\section{CSR Expenditure on Future Financial} Performance

Based on the test results above, CSR expenditure has no significant effect on future financial performance. This result is supported by Wafiatun \& Linda (2014), Marissa et al. (2013), and Felyna (2013) which stated that the disclosure of CSR does not affect the financial performance of a company. However, the firm size and leverage variables will affect future financial performance. The result is slightly different from the previous studies in which Sayekti (2015), Ridho (2018), Cho\&Park (2015), and Bhardwaj et al. (2018) stated that CSR expenditure has a significant effect on the future financial performance. Although CSR generally creates a good corporate image as reported by Rosdwianti (2016), it does not ensure customer loyalty and attracts investors so that it does not improve future financial performance. Therefore, $\mathrm{H}_{1}$ is rejected and is not following stakeholder theory because CSR expenditure is not affecting future financial performance.

\section{CSR Expenditure on Corporate Social} $\underline{\text { Activity }}$

The results of this research showed that CSR expenditure affects Corporate Social Activity (CSA) while firm size, profit, and leverage do not affect Corporate Social Activity. Therefore, if the company's CSR expenditures increases, the company would do more Corporate Social Activity. However, the size of the company, profit, and leverage do not guarantee that there will be more CSA activities carried out by the company. Thus $\mathrm{H}_{2}$ is accepted because CSR expenditure as an indicator of CSR affects CSA.

\section{Conclusion}

This research was conducted to determine the effect of CSR expenditure on future financial performance and CSA. This study analyzed the independent variable, CSR, as proxied by CSR expenditure, and dependent variables, future financial performance, as proxied by ROA, and corporate social activity. Further, for supporting variables, the firm size is proxied by total assets, the leverage is proxied by Debt to Assets Ratio (DAR), and the profit is measured by company profits for a year. The results of the research prove that CSR expenditure has no significant effect on future financial performance. Greater CSR expenditure does not guarantee the greater future financial performance of a company. Even though a company does not receive future financial performance from its CSR activities, the company will still report their CSR expenditure as a signal to the users of financial statements. The result is in 
accordance with the signalling theory, where this theory focuses on reducing asymmetry information from the internal and external companies.

Further, CSR expenditure has a significant effect on corporate social activity (CSA). Therefore, it can be concluded that Corporate Social Activity (CSR) insem manufacturing companies in the consumer goods industry registered in Bursa Efek Indonesia (BEI) is carried out with the aim of doing social activities instead of seeking profit in the future.

This research shows the relationship between CSR with future financial performance and CSR activities, where the results of this study indicate that the company conducts CSR intending to carry out social activities. Therefore, the result of this research can be used by the companies to have CSR activities involving their consumers. In addition, the result of this research could also be used by shareholders, investors, and other companies who want to build a working relationship with a particular company. The shareholders, investors, and other companies can choose to work with the ones that have an excellent image seen from their CSR. The limitation of this research is that not all companies transparently present the data on CSR Expenditure and report the company's CSR activities.

It is recommended, for future studies, to use other variables as a moderating variable in measuring the relationship of CSR and financial performance, such as Return on Equity (ROE) or Earning Per Share (EPS). It is also recommended for further research to use a more extended research period with the aim of better research results. Meanwhile, companies are expected to be more active and transparent in reporting their CSR.

\section{Reference}

Andreas, H. H., Sucahyo, U. S., \& Elisabeth, D. (2015). Corporate social responsibility dan profitabilitas. Jurnal Manajemen, 15(1), 119-136.

Barnett, M. L. (2007). Stakeholder influence capacity and the variability of financial returns to corporate social responsibility. Academy of Management Review, 32(3), 794-816. https://doi.org/10.5465/AMR.2007.25 275520

Benabou, R., \& Tirole, J. (2010). Individual and corporate social responsibility. Economica, 77(305), 1-19. https://doi.org/10.1111/j.14680335.2009.00843.x

Bhardwaj, P., Chatterjee, P., Demir, K. D., \& Turut, O. (2018). When and how is corporate social responsibility profitable? Journal of Business Research, 84(November 2017), 206219.

https://doi.org/10.1016/j.jbusres.2017. 11.026

Campbell, J. (2007). special topic forum on corporations as social change agents why would corporations behave in socially responsible ways? an institutional theory of corporate social responsibility. Lecture 3, 32(3), 946967. https://doi.org/10.5465/AMR.2007.25 275684

Chang, S. E. (2018). Has indonesia's unique progressivism in mandating corporate social responsibility achieved its ends? Sriwijaya Law Review, 2(2), 131. https://doi.org/10.28946/slrev.vol2.iss 2.131.pp131-151

Cho, E., \& Park, H. (2015). Is csr really profitable? Evidence from korea. Journal of Applied Business Research, 31(6), 1179-1198.

Crane, A., Matten, D., Spence, I. (2008). Corporate Social Responsability: In a Global Context.

Crowther, D., \& Aras, G. (2008). Corporate Social Reposibility. Retrieved from 
http://mdos.si/Files/definingcorporate-social-responsibility.pdf

Donaldson, T., \& Preston, E. L. (1995). The stakeholder theory of the corporation: concepts, evidence, and implications. Corporate Reputation Review, 25(4), 65-92.

https://doi.org/10.1177/017084060606 7995

European Commission. (2006). Communication from the commission to the european parliament, the council and the european economic and social committee implementing. Commission of The European Communities.

Falirat, T. S., Maramis, J. B., Manajemen, J., Sam, U., \& Manado, R. (2018). Perusahaan pada industri farmasi di bei periode 2012-2016. 6(2), 9981007.

Felyna, P. (2013). Pengaruh pengungkapan corporate social responsibility (csr) terhadap profitabilitas pada perusahaan high profile yang terdaftar di bei periode 2009-2011.

Freeman, R. E., Harrison, J. S., Wicks, A. C., Parmar, B., \& de Colle, S. (2010). Stakeholder theory: the state of the art. Stakeholder Theory: The State of the Art, 4(1), 1-343. https://doi.org/10.1017/CBO97805118 15768

Ghozali, I. (2016). Aplikasi analisis multivariete dengan program ibm spss 23 (Edisi 8). Semarang: Badan Penerbit Universitas Diponegoro.

Hong, H. G., Kubik, J. D., \& Scheinkman, J. A. (2012). Financial constraints on corporate goodness. Ssrn. https://doi.org/10.2139/ssrn.1734164

Irawati, D. E. (2012). Pengaruh struktur modal, pertumbuhan laba, ukuran perusa- haan dan likuiditas terhadap kualitas laba. Accounting Analysis Journal, 3(1), 361-369. https://doi.org/ISSN 2252-6765

Iskandar. (2016). Pengaruh penerapan corporate social responsibility. Forum Ekonomi, 18(1), 76-84.

Kurniasari, R. (2017). Analisis return on assets ( roa) dan return on equity terhadap rasio permodalan ( capital adequacy ratio ) pada pt bank sinarmas tbk. $I V(2)$.

Lozano, J. M. (2005). Towards the relational corporation: from managing stakeholder relationships to building stakeholder relationships (waiting for copernicus). Corporate Governance, $5(2)$, 60-77. https://doi.org/10.1108/147207005105 62668

Lys, T., Naughton, J. P., \& Wang, C. (2015). Signaling through corporate accountability reporting. Journal of Accounting and Economics, 60(1), 56-72.

https://doi.org/10.1016/j.jacceco.2015. 03.001

Marissa, Y., Dianne, F., \& Rizky, E. (2013). Corporate Social Responsibility. 2(1), 1-19.

Meilanny, B., \& Raharjo, S. T. (2016). Corporate social responsibility (csr) dari sudut pandang perusahaan. 4, 13-29.

Mitchell, R. K., Agle, B. R., \& Wood, D. J. (1997). Toward a theory of stakeholder identification and salience: Defining the principle of who and what really counts. Academy of Management Review, 22(4), 853.

Nisa, A. (2018). Pengaruh kepemilikan menejemen, kepemilikan institusional, corporate social responsibility dan profitabilitas terhadap nilai perusahaan. Universitas Muhammadiyah Purwokerto.

Papaioannou, G. J., \& Karagozoglu, A. K. (2017). Theories of new issue pricing. Underwriting Services and the New Issues Market, 135-143. https://doi.org/10.1016/b978-0-12803282-4.00009-2

Pratama, Y. H., \& Achmad, T. (2015). Pengaruh intellectual capital terhadap kinerja perusahaan dengan competitive advantage sebagai variabel intervening ( studi pada perusahaan perbankan yang terdaftar di bei 2009-2013 ). 4, 1-11. 
Ridho, T. K. (2018). The development of csr implementation in indonesia and its impact on company's financial and non-financial performance. $K n E$ Social Sciences, 3(8), 324. https://doi.org/10.18502/kss.v3i8.2517

Rosdwianti, M. K., \& Zahroh, Z. A. (2016). Pengaruh corporate social responsibility ( $c s r$ ) terhadap profitabilitas perusahaan ( studi pada sektor industri barang konsumsi yang terdaftar di bursa efek indonesia periode 2013-2014 ). 38(2), 16-22.

Sayekti, Y. (2015). Strategic corporate social responsibility (csr), company financial performance, and earning response coefficient: empirical evidence on indonesian listed companies. Procedia - Social and Behavioral Sciences, 211, 411-420. https://doi.org/10.1016/j.sbspro.2015. 11.054

Spence, M. (1973). Job market signaling author ( $\mathrm{s}$ ): michael spence source: the quarterly journal of economics , Vol . 87, No . 3 ( Aug ., 1973 ), pp . 355-374 Published by: The MIT Press Stable URL : http://www.jstor.org/stable/1882010. Press, The M I $T$ Journal, The Quarterly, 87(3), 355-374.

Spence, M. (2002). Signaling in retrospect and the informational structure of markets. American Economic Review, 92(3), 434-459. https://doi.org/10.1257/000282802601 36200

Su, W., Peng, M. W., Tan, W., \& Cheung, Y. L. (2016). The signaling effect of corporate social responsibility in emerging economies. Journal of Business Ethics, 134(3), 479-491. https://doi.org/10.1007/s10551-0142404-4

Utomo, D. S., Meylinasari, V., \& Machmuddah, Z. (2017). Biaya csr: voluntary disclosure, investasi dan sinyal? 24(1), 15-23.

Wafiatun, M., \& Linda Prasasti, K. (2014). Pengaruh corporate social responsibility terhadap profitabitabilitas pada perusahaan food and beverages di bursa efek indonesia (bei) tahun 2007-2010. (Sancall).

Widiastuty, E., \& Soewarno, N. (2019). Csr expenditure and company performance: charity or signal? Evidence from indonesia. 1745, 2237.

https://doi.org/10.12776/QIP.V23I3.1 273 


\section{APPENDIX}

\section{Normality Test Result of CSR Expenditure on Future Financial Performance}

\begin{tabular}{|l|l|l|}
\multicolumn{2}{|c}{} & \multicolumn{1}{l}{$\begin{array}{l}\text { Unstandardized } \\
\text { Residual }\end{array}$} \\
\hline $\mathrm{N}$ & Mean & 104 \\
\cline { 2 - 3 } & Std. Deviation & .0000000 \\
& & .94195996 \\
\hline $\begin{array}{l}\text { Most Extreme } \\
\text { Differences }\end{array}$ & Absolute & .087 \\
\cline { 2 - 3 } & Positive & .063 \\
\cline { 2 - 3 } & Negative & -.087 \\
\hline Test Statistic & & .087 \\
\hline Asymp. Sig. (2-tailed) & .050 \\
\hline
\end{tabular}

Normality Test Result of CSR Expenditure on Corporate Social Activity

\begin{tabular}{|l|l|l|}
\multicolumn{2}{c}{} & \multicolumn{1}{l}{$\begin{array}{l}\text { Unstandardized } \\
\text { Residual }\end{array}$} \\
\hline $\mathrm{N}$ & & 104 \\
\hline \multirow{3}{*}{ Normal Parameters } & Mean & .0000000 \\
\cline { 2 - 3 } & Std. Deviation & .65154238 \\
\hline $\begin{array}{l}\text { Most Extreme } \\
\text { Differences }\end{array}$ & Absolute & .071 \\
\cline { 2 - 3 } & Positive & .060 \\
\cline { 2 - 3 } & Negative & -.071 \\
\hline Test Statistic & & .071 \\
\hline Asymp. Sig. (2-tailed) & & .200 \\
\hline
\end{tabular}

Multicollinearity Test of CSR Expenditure on Future Financial Performance

\begin{tabular}{|c|c|c|c|c|c|c|c|}
\hline \multirow{2}{*}{ Model } & \multicolumn{2}{|c|}{$\begin{array}{l}\text { Unstandardized } \\
\text { Coefficients }\end{array}$} & \multirow{2}{*}{$\begin{array}{c}\text { Standardized } \\
\text { Coefficients } \\
\text { Beta } \\
\end{array}$} & \multirow{2}{*}{$t$} & \multirow{2}{*}{ Sig. } & \multicolumn{2}{|c|}{$\begin{array}{c}\text { Collinearity } \\
\text { Statistics }\end{array}$} \\
\hline & $\mathrm{B}$ & $\begin{array}{l}\text { Std. } \\
\text { Error }\end{array}$ & & & & Tolerance & VIF \\
\hline (Constant) & & 2.140 & & $\begin{array}{l}- \\
6.872\end{array}$ & .000 & & \\
\hline $\begin{array}{l}\text { CSR } \\
\text { Expenditure }\end{array}$ & -.033 & .056 & -.076 & -.580 & .563 & .431 & 2.323 \\
\hline Frim Size & .357 & .083 & .566 & 4.286 & .000 & .425 & 2.353 \\
\hline Leverage & -.401 & .183 & -.193 & $-\overline{2.194}$ & .031 & .960 & 1.042 \\
\hline
\end{tabular}


Multicollinearity Test of CSR Expenditure on Corporate Social Activity

\begin{tabular}{|c|c|c|c|c|c|c|c|}
\hline \multirow{2}{*}{ Model } & \multicolumn{2}{|c|}{$\begin{array}{c}\text { Unstandardized } \\
\text { Coefficients }\end{array}$} & \multirow{2}{*}{$\begin{array}{c}\text { Standardized } \\
\text { Coefficients } \\
\text { Beta } \\
\end{array}$} & \multirow{2}{*}{$\mathrm{t}$} & \multirow{2}{*}{ Sig. } & \multicolumn{2}{|c|}{$\begin{array}{l}\text { Collinearity } \\
\text { Statistics }\end{array}$} \\
\hline & B & $\begin{array}{l}\text { Std. } \\
\text { Error }\end{array}$ & & & & Tolerance & VIF \\
\hline (Constant) & -3.889 & 1.805 & & $\overline{2} .155$ & .034 & & \\
\hline $\begin{array}{l}\text { CSR } \\
\text { Expenditure }\end{array}$ & .153 & .039 & .525 & 3.929 & .000 & .429 & 2.330 \\
\hline Frim Size & -.102 & .111 & -.238 & -.926 & .357 & .116 & 8.601 \\
\hline Profit & .063 & .070 & .207 & .909 & .365 & .148 & 6.764 \\
\hline Leverage & -.115 & .130 & -.081 & -.886 & .378 & .915 & 1.093 \\
\hline
\end{tabular}

Autocorrelation Test of CSR Expenditure on Future Financial Performance

\begin{tabular}{|c|c|c|c|c|c|c|c|c|c|c|}
\hline \multirow[b]{2}{*}{ Model } & \multirow[b]{2}{*}{$\mathrm{R}$} & \multirow[b]{2}{*}{$\begin{array}{c}\mathrm{R} \\
\text { Square }\end{array}$} & \multirow[b]{2}{*}{$\begin{array}{c}\text { Adjust } \\
\text { ed R } \\
\text { Square }\end{array}$} & \multirow{2}{*}{$\begin{array}{l}\text { Std. } \\
\text { Error } \\
\text { of the } \\
\text { Estimat } \\
\quad \mathrm{e}\end{array}$} & \multicolumn{4}{|c|}{ Change Statistics } & \multirow[b]{2}{*}{$\begin{array}{l}\text { Sig. F } \\
\text { Change }\end{array}$} & \multirow[b]{2}{*}{$\begin{array}{c}\text { Durbi } \\
\text { n- } \\
\text { Wats } \\
\text { on }\end{array}$} \\
\hline & & & & & $\begin{array}{c}\mathrm{R} \\
\text { Squar } \\
\mathrm{e} \\
\text { Chang } \\
\mathrm{e} \\
\end{array}$ & $\begin{array}{c}\mathrm{F} \\
\text { Change }\end{array}$ & $\begin{array}{c}\mathrm{df} \\
1\end{array}$ & df 2 & & \\
\hline 1 & $\begin{array}{l}.5 \\
09\end{array}$ & 259 & .237 & .95598 & 259 & 11.674 & 3 & $\begin{array}{l}10 \\
0\end{array}$ & .000 & 1.036 \\
\hline
\end{tabular}

Autocorrelation Test of CSR Expenditure on Corporate Social Activity

\begin{tabular}{|c|c|c|c|c|c|c|c|c|c|c|}
\hline \multirow[b]{2}{*}{ Model } & \multirow[b]{2}{*}{$\mathrm{R}$} & \multirow[b]{2}{*}{$\begin{array}{c}\mathrm{R} \\
\text { Square }\end{array}$} & \multirow[b]{2}{*}{$\begin{array}{l}\text { Adjust } \\
\text { ed R } \\
\text { Squar } \\
\text { e }\end{array}$} & \multirow[b]{2}{*}{$\begin{array}{c}\text { Std. } \\
\text { Error of } \\
\text { the } \\
\text { Estimate }\end{array}$} & \multicolumn{4}{|c|}{ Change Statistics } & \multirow[b]{2}{*}{$\begin{array}{l}\text { Sig. F } \\
\text { Change }\end{array}$} & \multirow[b]{2}{*}{$\begin{array}{c}\text { Durb } \\
\text { in- } \\
\text { Wats } \\
\text { on }\end{array}$} \\
\hline & & & & & $\begin{array}{c}\mathrm{R} \\
\text { Squar } \\
\mathrm{e} \\
\text { Chang } \\
\mathrm{e}\end{array}$ & $\begin{array}{c}\mathrm{F} \\
\text { Chang } \\
\mathrm{e}\end{array}$ & df 1 & $\begin{array}{c}\mathrm{df} \\
2\end{array}$ & & \\
\hline 1 & $\begin{array}{l}.4 \\
90\end{array}$ & .241 & .210 & .66457 & .241 & 7.840 & 4 & 99 & .000 & .913 \\
\hline
\end{tabular}

\section{Heteroscedasticity Testof CSR Expenditure on Future Financial Performance} Dependent Variable: Future Financial Performance

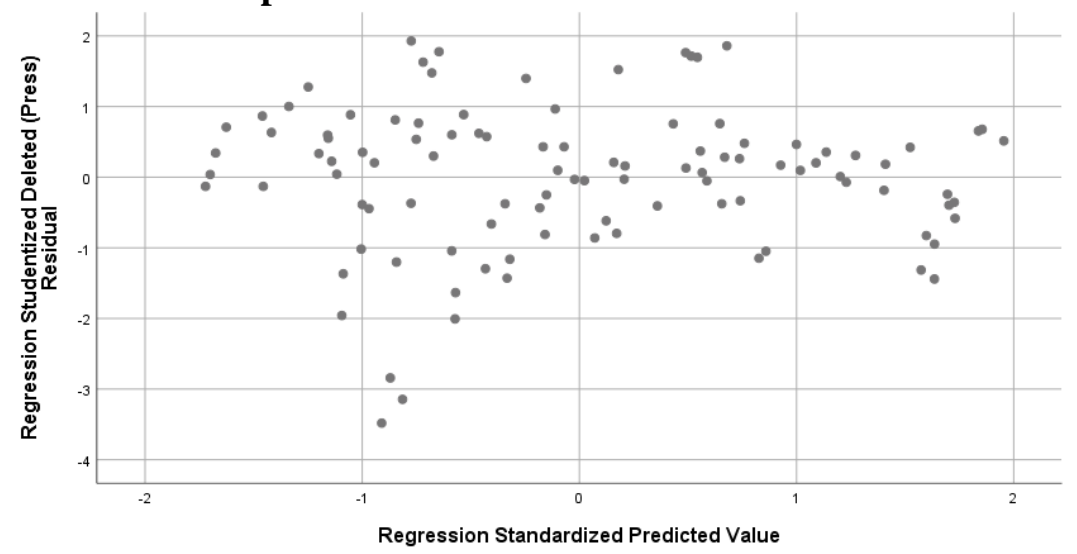


Heteroscedasticity Test of CSR Expenditure on Corporate Financial Performance

Dependent Variable: Corporate Social Activity

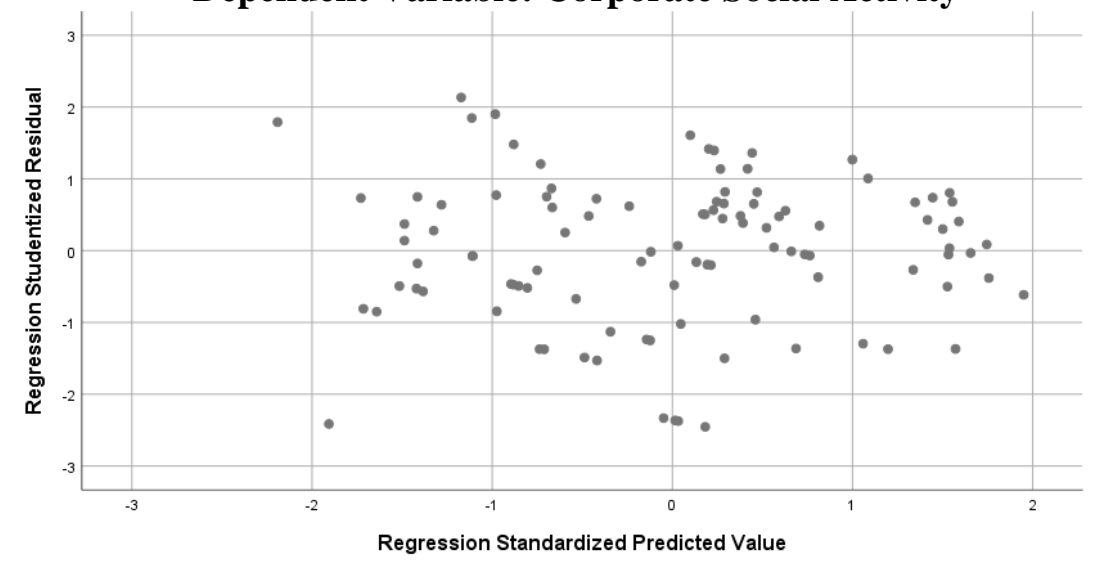

Partial Test (t-Test) of CSR Expenditure on Future Financial Performance

\begin{tabular}{|c|c|c|c|c|c|}
\hline \multirow{2}{*}{ Model } & \multicolumn{2}{|c|}{$\begin{array}{c}\text { Unstandardized } \\
\text { Coefficients }\end{array}$} & $\begin{array}{c}\text { Standardized } \\
\text { Coefficients }\end{array}$ & $\mathrm{t}$ & \multirow{2}{*}{ Sig. } \\
\cline { 2 - 4 } & $\mathrm{B}$ & Std. Error & Beta & & \\
\hline (Constant) & -14.703 & 2.140 & & -6.872 & .000 \\
CSR Expenditure & -.033 & .056 & -.076 & -.580 & .563 \\
Frim Size & .357 & .083 & .566 & 4.286 & .000 \\
Leverage & -.401 & .183 & -.193 & -2.194 & .031 \\
\hline
\end{tabular}

Partial Test (t-Test) of CSR Expenditure on Corporate Social Activity

\begin{tabular}{|c|c|c|c|c|c|}
\hline \multirow{2}{*}{ Model } & \multicolumn{2}{|c|}{$\begin{array}{c}\text { Unstandardized } \\
\text { Coefficients }\end{array}$} & $\begin{array}{c}\text { Standardized } \\
\text { Coefficients }\end{array}$ & \multirow{2}{*}{$\mathrm{t}$} & \multirow{2}{*}{ Sig. } \\
\cline { 2 - 4 } & $\mathrm{B}$ & Std. Error & Beta & & \\
\hline (Constant) & -3.889 & 1.805 & & -2.155 & .034 \\
CSR Expenditure & .153 & .039 & .525 & 3.929 & .000 \\
Frim Size & -.102 & .111 & -.238 & -.926 & .357 \\
Profit & .063 & .070 & .207 & .909 & .365 \\
Leverage & -.115 & .130 & -.081 & -.886 & .378 \\
\hline
\end{tabular}

Simultanneous Test (f-Test) of CSR Expenditure on Future Financial Performance

\begin{tabular}{|c|c|c|c|c|c|}
\hline Model & $\begin{array}{c}\text { Sum of } \\
\text { Squares }\end{array}$ & df & $\begin{array}{c}\text { Mean } \\
\text { Square }\end{array}$ & F & Sig \\
\hline Regression & 32.008 & 3 & 10.669 & 11.674 & .000 \\
\hline Residual & 91.391 & 100 & .914 & & \\
\hline Total & 123.399 & 103 & & & \\
\hline
\end{tabular}


Simultanneous Test (f-Test) of CSR Expenditure on Corporate Social Activity

\begin{tabular}{|c|c|c|c|c|c|}
\hline Model & $\begin{array}{c}\text { Sum of } \\
\text { Squares }\end{array}$ & df & $\begin{array}{c}\text { Mean } \\
\text { Square }\end{array}$ & F & Sig \\
\hline Regression & 13.850 & 4 & 3.463 & 7.840 & .000 \\
\hline Residual & 43.724 & 99 & .442 & & \\
\hline Total & 57.575 & 103 & & & \\
\hline
\end{tabular}

